\title{
Teaching Social Justice: A Proposal to Innovate the Liberal Arts Core
}

\author{
Joanne Ardovini ${ }^{1}$ and Anne Lopes ${ }^{2}$
}

The Metropolitan College of New York liberal arts core curriculum model innovates the liberal arts core and establishes social justices as its foundation. This "new" core was developed as an ability driven, information literate, interdisciplinary approach that integrates knowledge and skill into each course's design; while maintaining a studentcentered approach. How this curriculum represents a studentcentered approach toward social justice while improving student learning abilities, contributing to better learning outcomes, expanding career goals and giving students the necessary tools to use words to improve the world while making a living is the focus of this paper. [Article copies available for a fee from The Transformative Studies Institute. E-mail address: journal@transformativestudies.org Website: http://www.transformativestudies.org (C2009 by The Transformative Studies Institute. All rights reserved.]

KEYWORDS: Social Justice, Liberal Arts, Core Development, Purpose Centered Learning, Curriculum Development, Information Literacy, Service Learning, Student-Centered, Writing Across the Curriculum.

\section{INTRODUCTION}

Aside from the ongoing resistance to the "culture war's" legacy, a term originated in the work of Ira Shor which depicts the history of United States public schools as vehicles of Americanization and the continuing debate about the political, social, and economic content of schooling, the liberal arts core faces a host of challenges in our postmodern society (Spring 2005). While higher education has continued to democratize,

\footnotetext{
${ }^{1}$ Joanne Ardovini, Ph.D., is Associate Professor, Metropolitan College of New York. Address correspondence to: Joanne Ardovini, Metropolitan College of New York, 431 Canal Street, New York, NY 10013-1919; tel: (212) 343-1234, 2433; e-mail: JArdovini@Metropolitan.edu.

${ }^{2}$ Anne Lopes, Ph.D., is Associate Dean, Empire State College, Metropolitan Center. Address correspondence to: Anne Lopes, Associate Dean, Empire State College, Metropolitan Center, 325 Hudson Street, 5th Floor, New York, NY 10013; tel: (646) 230-1209.
} 